УДК 378.371

(С) Лебедєва К. О., 2021

http://orcid.org/0000-0001-7560-3226

DOI: $10.34142 / 23128046.2021 .51 .10$

К. О. Лебедєва

\title{
ЗАСТОСУВАННЯ РЕСУРСНОГО ПІДХОДУ ДО ФОРМУВАННЯ ПРОФЕСІЙНОЇ КОМПЕТЕНТНОСТІ У ЗДОБУВАЧІВ ВИЩОЇ ТЕХНІЧНОЇ ОСВІТИ
}

У статті доведено актуальність проблеми застосування ресурсного підходу до формування професійної компетентності у здобувачів вищої технічної освіти. Визначено суть професійної компетентності здобувачів вищої технічної освіти як інтегральної характеристики особистісних якостей фахівия, щуо відображає рівень знань, умінь, досвіду, яких необхідно і достатньо для досягнення мети певного роду діяльності, а також його професійноморальну позицію спеціаліста, яка полягає в готовності ставити перед собою цілі та приймати рімення, котрі забезпечують їх реалізацію, здійснювати професійну діяльність і спілкування на високому рівні. Розкрито потениіал ресурсного підходу для підвищення ефективності процесу формування означеної компетентності.

Суть ресурсного підходу визначено як сукупність технологій, способів, прийомів забезпечення виявлення й використання ресурсів і розвитку потенціалів особистості з метою підвищення ефективності різних видів діяльності, організаиії спілкування та стимулювання до самовдосконалення ци самоорганізації. Представлено методологічні підходи до застосування ресурсного підходу до формування професійної компетентності у здобувачів вищої технічної освіти (системний, синергетичний, компетентнісний, особистісно-діяльнісний, аксіологічний).

Визначено педагогічні умови успішного застосування ресурсного підходу до формування професійної компетентності у здобувачів вищої технічної освіти, щуо передбачають: здійснення цілеспрямованої психолого-педагогічної підготовки професорсько-викладацького складу до застосування ресурсного підходу в процесі формування професійної компетентності здобувачів вищої технічної освіти; забезпечення позитивної професійної мотивації студентів, стимулювання їх до розвитку ресурсних можливостей; оволодіння майбутніми фахівиями знаннями $і$ вміннями ращіональної самоорганізащії навчальнопізнавальної діяльності в прочесі професійної підготовки; створення у закладі вищої технічної освіти ергономічного освітнього середовища.

Презентовано форми і методи формування професійної компетентності у здобувачів вищої технічної освіти (проблемні бесіди, бесіди-роздуми, мінідискусії, тренінги, здоров'ябережувальні технології та ін.). 
Ключові слова: здобувач, вища технічна освіта, професійна компетентність, ресурсний підхід, заклад вищої технічної освіти, педагогічна умова, педагогічне забезпечення.

Lebedieva K. O. Application of the resource approach to the formation of professional competence of higher technical education applicants. The article proves the relevance of the problem of application the resource approach to the formation of professional competence of higher technical education applicants. The essence of professional competence of higher technical education applicants as an integral characteristic of personal qualities of a specialist is revealed, which reflects the level of knowledge, skills, experience, which are necessary and sufficient for achieving the goal of a certain kind of activity, as well as professional and moral position of a specialist, which is the readiness to set goals and make decisions that ensure their implementation, carry out professional activities and communication at a high level. The potential of the resource approach to increase efficiency of the formation process of this competence is revealed.

The essence of the resource approach is defined as a set of technologies, methods, techniques to identify and use resources and develop personal potential to increase the effectiveness of various activities, communication and incentives for self-improvement and self-organization. Methodological approaches to the application of the resource approach to the formation of professional competence of higher technical education applicants (systemic, synergetic, competence, personal-activity, axiological) are presented.

The pedagogical conditions of successful application of the resource approach to the formation of professional competence of higher technical education applicants are determined, which include: The pedagogical conditions of successful application of the resource approach to the formation of professional competence in applicants for higher technical education are determined, which include: implementation of purposeful psychological and pedagogical training of teaching staff for application of the resource approach in the process of forming professional competence of higher technical education applicants; ensuring students positive professional motivation, stimulating them to develop resource opportunities; mastering by future specialists knowledge and skills of rational self-organization of educational and cognitive activity in the process of professional training; creation of an ergonomic educational environment in the institution of higher technical education.

Forms and methods of professional competence formation of higher technical education applicants (problem conversations, reflections, mini-discussions, trainings, health saving technologies, etc.) are presented.

Key words: applicant, higher technical education, professional competence, resource approach, institution of higher technical education, pedagogical condition, pedagogical support.

Вступ. Сьогодні головна увага у професійній підготовці здобувачів вищої технічної освіти має бути зосереджена на розвитку в них професійної 
компетентності, яка дає можливість вчасно й оперативно реагувати на зміни у професійному середовищі, а також самостійно вдосконалювати професійні компетенції упродовж життя. На цьому акцентовано в законах України «Про освіту» (2017р.), «Про вищу освіту» (2014р.), «Про професійно-технічну освіту», у Національна стратегія розвитку освіти в Україні на період до 2021 року (2013 р.) та в інших нормативних документах.

Постійне підвищення вимог до професійної підготовки майбутніх фахівців технічної галузі, що постійно ускладнює зазначений процес, зумовлює необхідність забезпечення оптимізації освітнього процесу в закладах вищої технічної освіти (далі - ЗВТО).

Оптимізація процесу формування професійної компетентності майбутніх фахівців спирається на положення ресурсного підходу в педагогіці, який визначає сукупність умов і засобів, необхідних для реалізації потенційних можливостей студентів.

Освіта як ресурс розвитку особистості майбутнього фахівця знаходить виявлення у проектуванні освоєння здобувачем вищої освіти професійною компетентністю, підтримці інновацій у освітньому середовищі ЗВТО, інвестиціях, варіативності цілей, змісту, форм і методів упливу на особистість студента, розкриття і збереження його внутрішніх ресурсів, творчого потенціалу тощо.

Головною причиною актуалізації проблеми застосування ресурсного підходу до формування професійної компетентності в майбутніх фахівців полягає в тому, що зазначений підхід сприяє побудові освітнього простору закладів вищої освіти, орієнтованого на оптимізацію організації освітнього процесу, особистісно-індивідуальний розвиток здобувача освіти, що виявляється у забезпеченні індивідуальної траєкторії його розвитку й професійної самореалізації, розкритті особистісного потенціалу. Саме ресурсний підхід до формування професійної компетентності здобувача вищої технічної освіти передбачає: забезпечення ергономічності, варіативності диференціації, інноваційності в навчанні; вивчення, виявлення й реалізацію нових ресурсів у здобувача освіти.

Актуальність зазначеної проблеми посилюється виявленими під час нашого дослідження суперечностями, що існують у педагогічній теорії та практиці сучасних закладів вищої технічної освіти, як-от: між ускладненням професійної підготовки здобувачів освіти технічного профілю, обумовленим високими темпами розвитку науки й техніки, значним і постійним зростанням обсягу інформації, котрою мають оволодіти майбутні інженери під час навчання у ЗВТО, і недостатнім урахуванням внутрішніх ресурсів студентів у межах їхніх фізичних i часових витрат у процесі формування в них професійної 
компетентності; між необхідністю створення умов для виявлення й розвитку індивідуальних ресурсів у здобувачів вищої технічної освіти в процесі їхньої професійної підготовки i реальною практикою формування у студентів професійної компетентності, яка не забезпечує оптимальність і ефективність означеного процесу.

Вивчення наукової літератури з означеної проблеми засвідчує, що окремі аспекти проблеми формування професійної компетентності здобувачів вищої освіти технічної галузі розкрито в дослідженнях багатьох учених (Л. Грень, С. Даньшева, О. Ігнатюк, О. Кабацкая, Н. Кононець, М. Лазарєв, Л. Марцева, О. Пономарьов, А. Слободянюк, Л. Товажнянський та інші). Аналіз наукових праць із означеної проблематики дає підстави для висновку про вагомий внесок науковців у дослідження різних аспектів формування професійної компетентності студентів закладів вищої технічної освіти. Воднораз проблема застосування ресурсного підходу до формування професійної компетентності здобувачів вищої технічної освіти досліджена недостатньо.

Мета та завдання. Розкрити теоретико-методологічні засади застосування ресурсного підходу до формування професійної компетентності у здобувачів вищої технічної освіти, визначити педагогічні умови успішного формування професійної компетентності у студентів ЗВТО та презентувати педагогічне забезпечення визначених умов.

Методи дослідження. Під час наукового пошуку використовувався комплекс методів науково-педагогічного дослідження: теоретичних (вивчення та узагальнення наукових ідей і поглядів, викладених у філософській, педагогічній, психологічній літератури з проблеми дослідження; аналіз педагогічного досвіду, причинно-наслідковий аналіз отриманих емпіричних даних); емпіричних (експериментальна робота, спостереження, анкетування, тестування, індивідуальні бесіди, рефлексія, експертна оцінка).

Результати. Узагальнення різних підходів учених до розуміння суті поняття «компетентність» дало можливість розкрити цей феномен як результат оволодіння людиною певною компетенцією, що передбачає наявність у неї достатнього рівня сформованості знань, умінь, особистісних якостей та досвіду здійснення певної діяльності (Lozova \& Mikityuk, 2012; Martseva, 2015; Mikityuk, 2011). Компетенцію визначаємо як певну попередньо задану вимогу (норму) до підготовки майбутнього фахівця, що являє собою сукупність особистісних властивостей (знань, умінь, навичок тощо), необхідних для якісної продуктивної діяльності в процесі навчання та майбутній професійній діяльності.

Професійну компетентність розглядаємо як інтегральну характеристику особистісних якостей фахівця, що відображає рівень знань, умінь, досвіду, яких необхідно і достатньо для досягнення мети певного роду діяльності, а також його 
професійно-моральну позицію, яка виявляється в готовності ставити перед собою цілі та приймати рішення, котрі уможливлюють їх успішну реалізацію, здійснювати професійну діяльність і спілкування на високому рівні.

Особливості професійної компетентності сучасного здобувача вищої технічної освіти полягають у тому, що означена компетентність вимагає розвиненості особистісних якостей і вмінь, як-от: уміти самостійно набувати знання впродовж життя, бути мобільним i здатним гнучко й швидко адаптуватися у життєвих і професійних ситуаціях, які швидко змінюються; критично мислити, уміти бачити в реальній дійсності проблеми та, використовуючи сучасні технології, шукати шляхи раціонального їх застосування; бути здатними генерувати нові ідеї; самовдосконалювати власну професійно-моральну позицію, розвивати інтелектуальний потенціал, підвищувати культурний рівень; раціонально використовувати комп'ютерну техніку; застосовувати власні ресурсні можливості для професійного самовдосконалення.

Ресурсний підхід визначаємо як сукупності технологій, способів, прийомів забезпечення, виявлення й використання ресурсів i розвитку внутрішніх потенціалів особистості 3 метою підвищення ефективності різних видів діяльності, організації спілкування та стимулювання до самовдосконалення й самоорганізації.

Цілеспрямований, спеціально організований процес формування професійної підготовки здобувачів вищої технічної освіти на засадах ресурсного підходу має бути спрямованим на використання тих резервних можливостей, які б давали змогу студентові вийти на більш високий рівень професійної компетентності й стати передумовою успішності їхньої навчально-пізнавальної діяльності, сприяючи оптимізації освітнього процесу та всебічному розвитку в ньому потенціалів студентів, що, у свою чергу, впливає на особистісну та професійну самореалізацію і самовдосконалення здобувачів освіти.

Успішне формування професійної компетентності здобувачів вищої технічної освіти на засадах ресурсного підходу можливе за наявності відповідних педагогічних умов, які розглядаємо як взаємопов'язану сукупність внутрішніх параметрів і зовнішніх впливів на функціонування певного процесу (у нашому випадку - процесу формування професійної компетентності), що забезпечує його ефективність і відповідає психолого-педагогічним критеріям оптимальності.

Під час визначення й обгрунтування педагогічних умов успішного застосування ресурсного підходу до формування професійної компетентності у здобувачів вищої технічної освіти враховували: 
- результати наукових праць 3 проблеми формування професійної компетентності майбутніх фахівців радіотехнічної галузі та застосування ресурсного підходу в освіті (Lebedieva, 2018; Lebedieva \& Popova, 2018; Ibragim, 2009; Karapuzova, Pochinok \& Pomogaybo, 2012; Loseva, 2002; Martseva, 2015);

- психолого-фізіологічні властивості індивідуальних ресурсів особистості та ії потенціалу;

- логіку процесу формування професійної компетентності здобувачів вищої технічної освіти, який передбачає організаційно-підготовчий, діагностико-проєктувальний, стимулювально-інтенційний, змістоводіяльнісний та рефлексивно-самотворчий етапи;

- ідеї та положення системного, синергетичного, компетентнісного, аксіологічного, особистісно-діяльнісного та ергономічного підходів, які тісно пов'язані з упровадженням ресурсного підходу до формування професійної компетентності здобувачів вищої технічної освіти.

У процесі дослідження нами визначено і обгрунтовано педагогічні умови успішної реалізації ресурсного підходу до формування професійної компетентності здобувачів вищої технічної освіти, які мають передбачати (Mikityuk, 2011; Ozarko, Knish \& Moyseenko, 2014):

1) здійснення цілеспрямованої психолого-педагогічної підготовки професорсько-викладацького складу до використання ресурсного підходу в процесі формування професійної компетентності здобувачів вищої технічної освіти;

2) забезпечення позитивної професійної мотивації здобувачів освіти, стимулювання їх до розвитку ресурсних можливостей;

3) оволодіння майбутніми фахівцями знаннями і вміннями раціональної самоорганізації навчально-пізнавальної діяльності в процесі професійної підготовки;

4) створення у ЗВТО ергономічного освітнього середовища.

Для забезпечення умов успішного застосування ресурсного підходу до формування професійної компетентності здобувачів вищої технічної освіти було вжито низку заходів.

Так, здійснення цілеспрямованої психолого-педагогічної підготовки професорсько-викладацького складу до використання ресурсного підходу в процесі формування професійної компетентності здобувачів вищої технічної освіти, що передбачалося першою умовою, здійснювали шляхом:

- організації різнопланової інформаційно-роз'яснювальної роботи;

- упровадження комплексу науково-методичних заходів (проведення науково-методичного семінару «Застосування ресурсного підходу до формування професійної компетентності студентів», надання консультацій 
тощо);

- стимулювання викладачів до здійснення власних науково-методичних розвідок у сфері досліджуваної нами проблеми.

Із метою реалізації другої умови застосовували: проблемні бесіди, бесідироздуми, вебінари, міні-дискусії (наприклад, «Імідж сучасного фахівця технічної галузі», «Що нового я можу привнести в свою професію», «Я вважаю, що зможу досягти успіху в майбутній професійній діяльності, адже я ...», «Роздуми про власне «Я» у професії» тощо); ділові ігри: «Стратегія усунення конфліктів» (зокрема, навчальна дисципліна «Психологія екстремальних стосунків та ефективної адаптації»), «Лідер» (навчальна дисципліна «Імідж сучасного фахівця технічної галузі»); «Прийняття управлінського рішення» (навчальна дисципліна «Психологія управління») із використанням імітаційних комп'ютерних програм; тренінги (міжособистісного спілкування, мотивації досягнення успіху, самопізнання, імідж-тренінг тощо).

Для реалізацї третьої умови було розроблено і впровадження спецкурс для майбутніх фахівців «Наукова самоорганізація діяльності студентів», метою якого було цілеспрямоване і системне оволодіння здобувачами освіти знаннями i вміннями самоорганізації навчально-пізнавальної діяльності (щодо планування, способів і засобів наукової організації праці (передусім, розумової), гігієни розумової праці тощо).

Також у процесі реалізації третьої умови майбутніх фахівців долучали до активної самовиховної діяльності.

Робота із забезпечення четвертої умови успішного застосування ресурсного підходу до формування професійної компетентності здобувачів вищої технічної освіти була спрямована на створення у ЗВТО ергономічного освітнього середовища. Така робота вимагала забезпечення комплексу психолого-педагогічних факторів, як-от: творчу взаємодію всіх учасників освітнього процесу; усунення жорсткого регламенту в процесі навчання; створення ситуацій багатоваріативності під час розв'язання різноманітних завдань у різних видах і напрямах професійної підготовки; позитивне ставлення до активізації роботи всіх суб'єктів освітнього процесу, спрямованої на реалізацію ресурсного підходу до формування професійної компетентності здобувачів освіти; застосування здоров'язбережувальних технології та підтримувальних психолого-педагогічних технік із метою розкриття індивідуальних ресурсних можливостей кожного здобувача освіти; здійснення психолого-педагогічного супроводу студентів (Ozarko, Knish \& Moyseenko, 2014).

Обговорення. Аналіз дисертаційних досліджень і наукових публікацій (Ю. Ібрагім, Т. Цецоріна, Д. Леонтьєв, В. Лозова, А. Маркова, С. Микитюк, 
В. Михайличенко, О. Романовський та інші) дає підстави свідчити про підвищення інтересу науковців до проблеми застосування ресурсного підходу до формування професійної компетентності здобувачів вищої технічної освіти. Проте вивчення стану розробленості порушеної проблеми дозволяє дійти висновку, що в означеній галузі ще існує ціла низка невирішених питань як теоретичного, так і прикладного характеру. Зокрема, наразі не існує одностайної думки щодо методологічних засад застосування ресурсного підходу в сучасних ЗВТО, розробки технології та педагогічних умов формування професійної компетентності майбутніх фахівців технічної галузі на основі ресурсного підходу, їх науково-методичного забезпечення тощо. Отримані нами результати науково-дослідної роботи в цілому збігаються із здобутками інших дослідників (Б. Ананьєв, С. Дружилов, Ю. Ібрагім, О. Ігнатюк, В. Лозова, Н. Лосєва, С. Микитюк, В. Сластьонін та ін.). Воднораз, порівняно з попередніми працями, у статті представлено авторський підхід до визначення педагогічних умов розв'язання досліджуваної проблеми, подальшого розвитку набули форми i методи забезпечення визначених умов у практиці сучасних ЗВТО. Уважаємо, що в подальшому науковцям слід більше уваги приділити пошуку інноваційних форм, методів, технологій оптимізації освітнього процесу у ЗВТО із метою збереження ресурсних можливостей студентів та їхньої професійної самореалізації, підготовці професорсько-викладацького складу та майбутніх працівників освітньої сфери до застосування ресурсного підходу в професійній освіті, що має стати перспективними напрямами подальших наукових розвідок.

Висновки. Оптимізація процесу формування професійної компетентності майбутнього фахівця вимагає звернення до ресурсного підходу, який сприяє побудові освітнього простору, орієнтованого на розвиток індивідуальності, збагаченню теорії й практики індивідуалізації навчання; оптимальній організації навчально-пізнавальної діяльності здобувачів вищої освіти, що знаходить прояв у принципах оптимальності, ергономічності, забезпечення індивідуальної траєкторії розвитку майбутнього фахівця, реалізації його особистісного потенціалу в процесі професійної підготовки.

Активний розвиток ресурсних можливостей особистості майбутнього фахівця відбувається в процесі його професійної самореалізації, суть якої відбиває самостійне прагнення здобувача освіти до максимального саморозкриття внутрішніх ресурсів, передбачення результатів власного професійного становлення і самовдосконалення.

Педагогічні умови успішного застосування ресурсного підходу до формування професійної компетентності у здобувачів вищої технічної освіти мають передбачати: здійснення цілеспрямованої психолого-педагогічної підготовки професорсько-викладацького складу до використання ресурсного 
підходу в процесі формування професійної компетентності здобувачів вищої технічної освіти; забезпечення позитивної професійної мотивації здобувачів освіти, стимулювання їх до розвитку ресурсних можливостей; оволодіння майбутніми фахівцями знаннями i вміннями раціональної самоорганізації навчально-пізнавальної діяльності в процесі професійної підготовки; створення у ЗВТО ергономічного освітнього середовища.

\section{ЛITEPATУPA:}

Lebedieva K.O. Pedagogical conditions of students' professional competence formation of technical educational institutions on the basis of the resource approach. Educational Studios: Theory and Practice: monograph / edit. I.M. Trubavina, S.T. Zolotukhina. Prague - Vienna: Premier Pudlsshing, 2018, 340-346.

Lebedieva K.O., Popova O.V. Interconnection of Recourse And Ergonomic Approaches As A Condition Of Optimization Of The Process Of Students' Professional Competence Formation In The Educational Environment Of Higher Technical Education Institution. Educational Studios: Theory and Practice: monograph / edit. I.M. Trubavina, S.T. Zolotukhina. Vienna: Premier Pudlsshing, 2019, 21-29.

Ібрагім Ю. С. Етапи формування культури розумової праці на основі ресурсного підходу. Науковий часопис. НПУ ім. М. П. Драгоманова. Проблеми трудової та професійної підготовки : зб. наук. праць. К. : Стиль Іздат, 2009. Вип.7. С.74-83.

Карапузова Н. Д., Починок Є. А., Помогайбо В. М. Основи педагогічної ергономіки: Навч. посібник для студентів вищих навч. закладів. К. : «Академвидав», 2012.

Лозова В. І., Микитюк С. О. Ресурсний підхід. Наукові підходи до педагогічних досліджень: колективна монографія. Харків, 2012. С.166-187.

Лосєва Н.М. Фізичне здоров'я - умова самореалізації особистості. Педагогіка, психологія та медико-біологічні проблеми фізичного виховання і спорту: зб. наук. праць. Харків: Харківська держ. акад. дизайну і мистец. 2002. № 13. С. 21-27.

Марцева Л. А. Професійна підготовка молодших спеціалістів радіотехнічного профілю в технічних коледжах : монографія. Вінниця : Тезис, 2015. 438 с.

Микитюк С. О. Ресурсна концепція управління освітнім процесом у сучасному вищому навчальному закладі. Засоби навчальної та науково-дослідної роботи : зб. наук. прачь Х., 2011. Вип. 36. С. 78-87.

Озарко І. І., Книш Л. О., Мойсеєнко Н. В. Формування професійної компетентності майбутніх інженерів-гірників. Вісник Житомирського державного університету. Педагогічні науки. Вип. 3 (75). 2014. С.71-81.

\section{REFERENCES:}

Lebedieva, K. O. (2018). Pedagogical conditions of students' professional competence formation of technical educational institutions on the basis of the resource approach. Educational Studios: Theory and Practice: monograph / edit. I.M. Trubavina, S.T. Zolotukhina. Prague - Vienna: Premier Pudlsshing. P. 340-346.

Lebedieva, K. O. \& Popova, O.V. (2018). Interconnection of Recourse And Ergonomic Approaches As A Condition Of Optimization Of The Process Of Students' Professional Competence Formation In The Educational Environment Of Higher Technical Education Institution. Educational Studios: Theory and Practice: monograph / edit. I.M. Trubavina, S.T. Zolotukhina. Vienna: Premier Pudlsshing. P. 21-29.

Ibragim, Yu. S. (2009). Etapi formuvannya kulturi rozumovoyi pratsi na osnovi resursnogo pidhodu. [Stages of Formation of the Culture of Mental Work on the Basis of the Resource Approach]. Naukoviy chasopis. NPU Im. M. P. Dragomanova. Problemi trudovoYi ta profeslynoYi pIdgotovki : zb. nauk. prats. K. : Stil Izdat. Vip.7. S.74 (in Ukrainian). 
Karapuzova, N. D., Pochinok, E. A. \& Pomogaybo, V. M. (2012). Osnovi pedagogichnoyi ergonomiki [Fundamentals of Pedagogical Ergonomics]: Navch. posibnik dlya studentiv vischih navch. Zakladiv. Kiyiv, «Akademvidav», 2012 (in Ukrainian).

Lozova, V. I. \& Mikityuk, S. O. (2012). Resursniy pidhid [Resource Approach]. Naukovi pidhodi do pedagogichnih doslidzhen: kolektivna monografIya. Harkiv. S.166 (in Ukrainian).

Loseva, N. M. (2002). FIzichne zdorov'ya - umova samorealizatsiyi osobistosti [Physical Health is a Condition of Self-realization]. Pedagogika, psihologIya ta mediko-bIologIchnI problemi fIzichnogo vihovannya i sportu: zb. nauk. prats. HarkIv: Harkivska derzh. akad. dizaynu i mistets. \# 13. S. 21-27 (in Ukrainian).

Martseva, L. A. (2015). ProfesIyna pIdgotovka molodshih spetsIalIstIv radIotehnIchnogo profIlyu v tehnIchnih koledzhah [Professional Training of Junior Specialists in Radio Engineering in Technical Colleges] : monografiya. Vinnitsya : Tezis. 438 s. (in Ukrainian).

Mikityuk, S. O. (2011). Resursna kontseptsIya upravlInnya osvItnIm protsesom u suchasnomu vischomu navchalnomu zakladi [Resource Concept of Educational Process Management in a Modern Higher Education Institution]. Zasobi navchalnoyi ta naukovo-doslidnoyi roboti : $\mathrm{zb}$. nauk. prats H. Vip. 36. S. 78. (in Ukrainian).

Ozarko, I. I., Knish, L. O. \& Moyseenko, N. V. (2014). Formuvannya profesiynoyi kompetentnosti maybutnih inzheneriv-girnikiv [Formation of Professional Competence of Future Mining Engineers]. Visnik Zhitomirskogo derzhavnogo universitetu. Pedagogichni nauki. Vip. 3 (75). 2014. S.71 (in Ukrainian).

\begin{tabular}{ll}
\multicolumn{1}{c}{ Інформація про авторів: } & \multicolumn{1}{c}{ Information about the authors: } \\
Лебедсва Катерина Олегівна: & Lebedieva Kateryna Olehivna: \\
ORCID: http://orcid.org/0000-0001-7560- & ORCID: http://orcid.org/0000-0001-7560- \\
3226; доктор філософіï, доцент кафедри & 3226; PhD, Associate Professor of the Foreign \\
іноземних мов, Харківський національний & Languages Department, Kharkiv National \\
університет радіоелектроніки, пр. Науки,14, & $\begin{array}{l}\text { University of Radio Electronics, Kharkiv, } \\
\text { Харків, Україна, 61166 }\end{array}$ \\
Nauky Ave. 14, Kharkiv, Ukraine, 61166 \\
e-mail: kateryna.lebedeva@nure.ua & kateryna.lebedeva@ nure.ua
\end{tabular}

Цитуйте цю статтю як: Лебедєва К. О. Застосування ресурсного підходу до формування професійної компетентності у здобувачів вищої технічної освіти. Теорія та методика навчання та виховання. 2021. № 51. С. 97-106.

DOI: $10.34142 / 23128046.2021 .51 .10$

Дата надходження статті до редакції: 25.10.2021

Стаття прийнята до друку: 12.11.2021 